\title{
7. Printing in the Service of the State
}

\section{Introduction}

The duplication of texts and illustrations with prefabricated moulds does not belong to the field of subsistence technologies but constitutes one of the cultural foundations of the East, West, and South Asian, European, and North African civilizations and is one of the basic requirements of most governments. Rulers strove to control this means of communication, even if on a different level than shipbuilding or the manufacturing of weapons.

In this section, we will explore printing in the service (and under the direct supervision) of the state as well as printing in the private economy with respect to the question whether the state exploited and tightly controlled the private sector. Moreover, on the basis of the model of dynastic rise, flourishing, and decline and the takeover by local elites and regional governments in the later part of the dynasties, we will inquire into the modernization efforts of the central and provincial governments. Finally, we will look at the situation of masters and workers in the printing trade and find clues about the social position of 'artisans' and 'merchants' in the trade.

Like its predecessors since the Song, the Qing dynasty used printing not only to distribute information to all levels of administration and to educate a narrower target group of pupils and students preparing for official examinations on the state orthodoxy but also to educate (jiaohua) all the emperor's subjects in morals. Unlike the preceding Ming rulers, the Qing were not Han Chinese. They spoke a different language and used a different script but still had to present themselves as the patrons and legitimate defenders of Han Chinese civilization. Had they not done so, they would have faced great difficulties in securing the administrative knowledge and skills of the Chinese scholar-official elite. And anything but co-operation was out of the question, given the numerical ratio of the Manchus to the Han Chinese. Therefore the Qing adopted and refined the state examinations as their basic method for fostering a meritocracy educated in the Confucian state orthodoxy with its texts and commentaries. However, the state orthodoxy of the Qing left room for other belief systems as long as they did not clash with the ruling system. From time to time, 
the government also sponsored printing projects of the basic religious texts of Buddhism. ${ }^{1}$

Technically, the craft of printing during the Qing was executed mainly as woodblock printing (xylography), which leaves the mirror image of the printing parts of the block in relief and cuts away all non-printing parts. To a much smaller extent, movable type made of wood, metal alloys based on copper or tin, clay, or enamel was also used. From the nineteenth century on, missionaries introduced lithography and letterpress printing with cast metal type, mainly lead. This type of printing was also promoted by the first foreign newspaper entrepreneurs in the treaty ports. Gravure printing with copperplate had been brought to the Qing court by missionaries in the early eighteenth century but did not become a broadly accepted medium in the private printing workshops.

On various levels, the government engaged in printing and established permanent or temporary printeries. The so-called 'palace editions' (dianben) stood out for their editorial, technical, and artistic quality throughout the dynasty. However, in this field of cultural production, the Qing court and central government took much longer to adopt new technologies and devices than in the military and shipbuilding sector. Printing did not belong to the top priorities for modernization before the twentieth century.

\section{Printing in the Palace: Scope and Output of the Workshops at the Hall of Martial Valour}

The single most famous printing agency of the central government was the printery in the Hall of Martial Valour (Wuying dian) within the Forbidden City. It was situated next to the western palace gate Xihua men, south of the administrative buildings of the Imperial Household Department - to which it was subordinate ${ }^{2}$ - and west of the central, highest-ranking throne hall Taihe dian, the Hall of Supreme Harmony (see Figures 17-19).

1 The largest government printing project for Buddhist texts was the Longzang 龍藏 (Dragon Tripitaka), comprising 1,662 works, which could be completed in the relatively short time of three years (1735 to 1738) by using some of the old printing blocks carved during the Ming period. See Tsien Tsuen-hsuin, Paper and Printing, p. 185.

2 On the relationship between the Wuying dian printery and the Imperial Household Department, see Yang Yuliang, 'Wuying dian xiushuchu ji neiwufu xiushu ge guan', especially the organizational charts on p. 39 and 40. 
Figure 17 Position of the Wuying dian Printery within the Imperial Palace in Peking

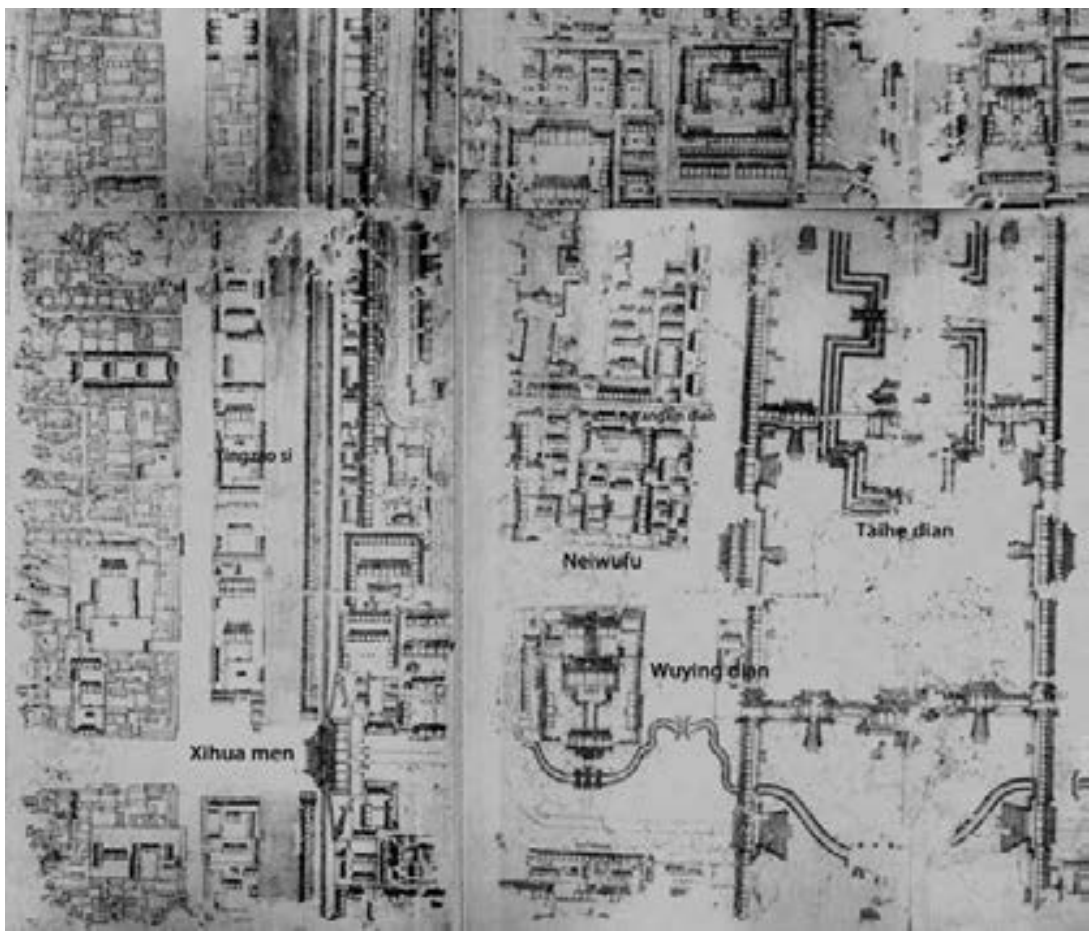

Source: Based on Kenryū keijō zenzu/Qianlong jingcheng quantu, fold 7, p. 6-7, and fold 8, pp. 6-7. ${ }^{3}$

During the Ming-Qing transition, the pretender Li Zicheng (16o6-1645) occupied the Ming palace in 1644 and chose this compound as his government seat. After the Manchus took over Peking later that year, the regent Dorgon set up his administrative seat here. In 1680, the production site Wuying dian Palace Workshop (Wuying dian zaobanchu) was first established here. In 1729, it was explicitly named Wuying dian Book Production Site (Wuying dian xiushu chu) after some workshops that were not directly related to printing - such as the ateliers of the ink slab makers, the enamel makers, and the painters - were relocated to the workshops at the palace

3 The importance and accuracy of the map of the Imperial City produced during the early years of the Qianlong reign (ca. 1740) has been pointed out by Yang Naiji, Qianlong Jingcheng quantu kaolue. For a recent investigation of palace workshops Yangxin dian zaoban chu on the basis also of this map, see Zhang Xueyu and Li Xiaocen's study 'Qinggong Zaobanchu chengli ruogan wenti xintan', p. 9. 
Figure 18 Entrance of the Main Hall of Wuying dian

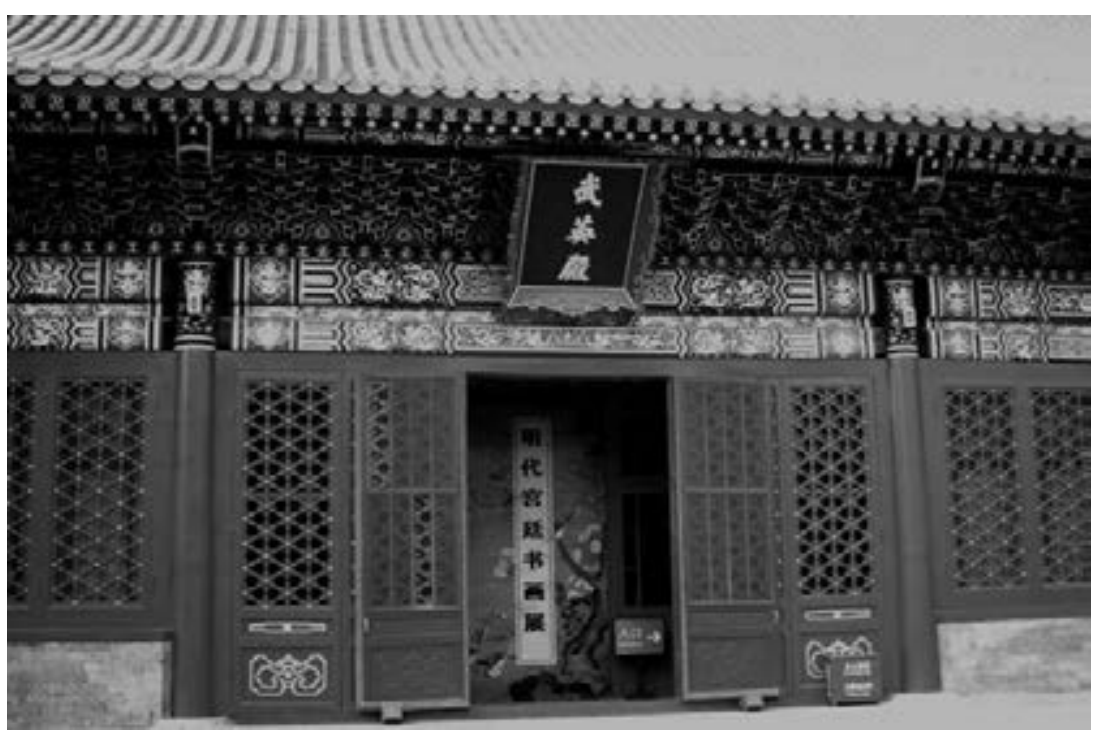

Figure 19 Entrance to the Wuying dian compound

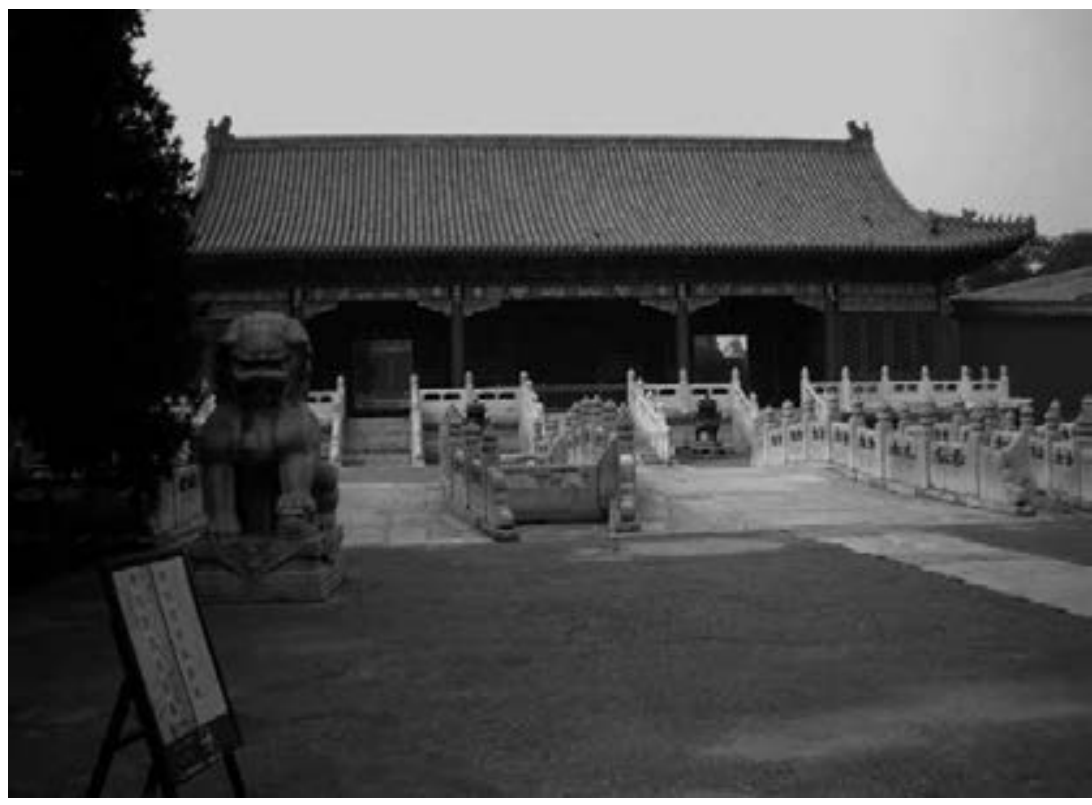

Source: Photographs taken by the author in August 2006, after the compound had been renovated and reopened to the public. 
hall Yangxin dian (Yangxin dian zaoban chu). ${ }^{4}$ Prior to 1680, printing had taken place in the Imperial Household Office of Rites, as under the Ming, and since the styles and layouts of early Qing printing strongly resembled that of the late Ming, it has been assumed that the Qing may have retained the personnel from the Ming palace printery, the so-called 'classics manufactory' (jingchang). ${ }^{5}$

The printing activities of the central government flourished between 1729 and c. 1805 . With a permanent staff of about one-hundred, the highest quality of materials, and sometimes even personal supervision by the emperors, the 'palace editions' were products of the highest quality that were distributed not only to the capital offices but also to the provincial governments. The government promoted the reproduction of these exemplars (model editions to be used for reprinting) by provincial government printeries and also by private publishers. The palace editions were also sold in less luxurious binding and paper.

Statistics on the total output of the Wuying dian are not available; Chinese book historians have estimated an output of at least 381 by $1805,{ }^{6}$ but an analysis of provincial holdings and the imperial library at the secondary capital Shenyang (Shengjing) reveals that the number of imprints until the end of the dynasty was $572 .{ }^{7}$ The texts include personal writings by the Qing emperors; histories of previous dynasties; reprints of the historical, philosophical, and literary writings of previous dynasties; records of military campaigns of the Qing and its expansion to the West; dictionaries, encyclopedias, and collectanea; literary works; and, last but not least, some works introducing European sciences, especially astronomy, cartography, and mathematics that were written by the Jesuit missionaries of the late seventeenth and early eighteenth century. The output of the palace printeries - expressed in the four traditional bibliographic categories of the Confucian canonical classics, histories (and all types of administrative guides and handbooks as well as legal codices), thinkers (including scientific and proto-scientific writings, fine arts, encyclopedias, as well as Buddhist and Daoist writings and canons), and literary collections (including prose, poetry, and drama) is as follows:

4 Liu Qiang, 'Qing Wuying dian', p. 266.

5 Ibid.

6 Lu Shaw, Imperial Printing, p. 15.

7 Liu Qiang, 'Qing Wuying dian', p. 266, referring to Zhu Saihong, 'Wuying dian', pp. 29-30, who quotes from the Annotated bibliography of Qing Imperial Household printings Qingdai neifu keshu mulu jieti. However, Zhu points out that not all 'Imperial printings' or 'palace copies' were produced in the Wuying dian. 
Table 31 Output of palace edition printings, in numbers of titles, since the foundation of the Wuying dian printery in 1680

\begin{tabular}{|c|c|c|c|c|c|c|c|}
\hline $\begin{array}{l}\text { Catego } \\
\text { [Number } \\
\text { of years] }\end{array}$ & $\begin{array}{l}\text { Canon } \\
\text { jing }\end{array}$ & $\begin{array}{l}\text { History } \\
\text { shi }\end{array}$ & $\begin{array}{l}\text { Thinkers } \\
\text { zi }\end{array}$ & $\begin{array}{l}\text { Literary } \\
\text { collections } \\
j i\end{array}$ & $\begin{array}{l}\text { Collectanea } \\
\text { congshu }\end{array}$ & Total & $\begin{array}{l}\text { Average } \\
\text { per year }\end{array}$ \\
\hline $\begin{array}{l}\text { Kangxi (1662) } \\
1680-1722 \text { [43] }\end{array}$ & 1 & 1 & 1 & & & 3 & 0.06 \\
\hline $\begin{array}{l}\text { Yongzheng } \\
\text { 1723-1735 [12] }\end{array}$ & 1 & 3 & 1 & & & 5 & 0.4 \\
\hline $\begin{array}{l}\text { Qianlong } \\
\text { 1736-1795 [60] }\end{array}$ & 31 & 156 & 28 & 24 & 148 & 387 & 6.45 \\
\hline $\begin{array}{l}\text { Jiaqing } \\
1796-1820 \text { [25] }\end{array}$ & & 38 & 6 & 27 & & 71 & 2.84 \\
\hline $\begin{array}{l}\text { Daoguang } \\
1820-1850 \text { [31] }\end{array}$ & 4 & 25 & 8 & 9 & & 46 & 1.48 \\
\hline $\begin{array}{l}\text { Xianfeng } \\
1851-1861 \text { [11] }\end{array}$ & 1 & 10 & 6 & 5 & & 22 & 2 \\
\hline $\begin{array}{l}\text { Tongzhi } \\
\text { 1862-1874 [13] }\end{array}$ & & 4 & 7 & 1 & & 12 & 0.92 \\
\hline $\begin{array}{l}\text { Guangxu } \\
\text { 1875-1908 [34] }\end{array}$ & & 7 & 12 & 1 & & 20 & 0.58 \\
\hline $\begin{array}{l}\text { Xuantong } \\
\text { 1909-1911 [3] }\end{array}$ & & 4 & & & & 4 & 0.75 \\
\hline Unknown date & 1 & 1 & & & & 2 & \\
\hline Total 268 [250] & 39 & 249 & 69 & 67 & 148 & 572 & 2.28 \\
\hline
\end{tabular}

Source: Zhu Saihong, 'Wuying dian', p. 30, referring to Qingdai neifu keshu mulu jieti.

Lu Shaw, in her account of the printer, dates the period of decline in printing to after 1805 . On the basis of recent research, the nineteenth century does not seem quite as bleak, but it is clear that the Qianlong era constitutes the peak of production of high-quality prints. In the nineteenth century, the printing activities at the Wuying dian were continued even though its finances were cut in the 1840 s due to urgent government expenses for the Opium War. A fire destroyed the greater part of the Wuying dian in 1869 as well as most books and some of the printing blocks. It was rebuilt but was struck by lightning in the Guangxu era; in 1901, the hall burned down once again. ${ }^{8}$ After 1869 , much of the printing was delegated either 
to provincial printing offices that proliferated and blossomed after the mid-nineteenth century or to private printing enterprises by mediation of the Office of Foreign Affairs (Zongliyamen). However, archival records show that on a much reduced scale, the Wuying dian printery was active until at least 1910. ${ }^{9}$ However, the main impetus and innovatory energy after the mid-nineteenth century was to be found in the provincial printeries and private printing enterprises.

\section{Large Printing Projects with Movable Types}

As the above table shows, the highest output of individual works was during the Qianlong era. Yet counting individual titles or titles in collections gives a skewed view. The huge encyclopedia Gujin tushujicheng (Complete collection of old and new illustrations and texts), which was begun under the Kangxi and finished under the Yongzheng emperor, is exceptional in its size, boasting over 10,000 chapters bound in 5,020 volumes, as well as being impressive in terms of the technical process of its production. ${ }^{10}$ The edition was printed with movable copper type in about sixty sets over three years from 1726 to 1728. ${ }^{11}$ An estimated 230,000 to 250,000 copper (or rather, brass) types were produced for the purpose. ${ }^{12}$ Present-day scholars generally believe that these types were not cast but carved. ${ }^{13}$ The type carvers received piece wages of 0.025 tael per type produced, while those carving wooden types were only paid 0.08 to 0.14 tael for one-hundred types. This is a difference that is more feasible if the types for the Gujin tushujicheng were carved, since it takes much more effort to carve metal than wooden types or to cast metal types. ${ }^{14}$

Paul Pelliot, 'Notes de bibliographie chinoise', Bulletin de l'Ecole française de l'Extrême-Orient, 2/1902. See also Zhu Saihong, 'Dianben', p. 60.

9 The booklet 30, 'Qianliang dice' 錢糧底冊 (Money and food provision accounts) of the Wuying dian documents in the First Historical Archives dates from 1910. Neiwufu ... boce, no. 432-5-41.

10 Lionel Giles, Index, p. ix, has estimated the volume of the Gujin tushujicheng to cover about three to four times the content of the eleventh edition of the Encyclopedia Britannica (1911, 29 vols.). According to Lothar Ledderose, Ten Thousand Things, p. 141, the compilation of this encyclopedia also inspired French and English encyclopedists who brought out the French Encyclopédie (printed 1751-1765) and the first edition of the Encyclopedia Britannica (printed 1768-1771).

11 See Lu Shaw, Imperial Printing, pp. 48-49, for the controversy on the number of sets printed.

12 In Korea, where printing with metal movable type was more common than in China, various alloys are known in which the copper content ranged between $5^{\circ}$ and 70 percent. See Table 32 .

13 Lu Shaw, Imperial Printing, p. 47.

14 'Wages for Printing'. 
However, the types were not preserved but in 1744 were melted down for coin production. Why this was done is not clear. The value of the carved types should have been much higher than that of mere scrap material for coinage. Moreover, the mass of brass alloy cannot have made an enormous difference to the output of monetary coins. Even assuming that the entire set of 250,000 types was melted down, this would have yielded between 700 and 800 strings of thousand cash, if the alloy was more or less the same as that used for coinage (see Table 32 ). In the 1740s, the Metropolitan Mints produced a yearly total of 700,000 to 1.5 million strings or 58,333 to 125,000 strings per month. ${ }^{15}$ Between 1741 and 1745 (Qianlong 6 to 10), the entire annual output has been estimated at an average of 2.1 million strings. ${ }^{16}$ The material obtained from the printery can therefore hardly have made a big difference in the monetary liquidity of the capital. The 'Palace history of the Qing' explains this action of recycling as a cover-up for graft. According to this source, the custodians of the copper type storehouse had stolen part of the types and, taking advantage of an actual shortage of coins in the capital, suggested to have the types melted down for coin production. ${ }^{17}$ Another source states that more than half of the original types were found to be missing; if that was so, even less was gained by melting the types. ${ }^{18}$

Several reasons may have prompted the emperor to consent to the destruction of the type. First, if there was a perception of an actual scarcity of material for coinage, and together with this, the notion that since the use of brass was time and again restricted or entirely forbidden by imperial decree, ${ }^{19}$ the court should show a good example and do away with all unnecessary items made of that scarce material. ${ }^{20}$ Or did the emperor

15 Vogel, 'Unrest and Strikes', p. 395.

16 Burger, 'Minting', p. 392.

17 Lu Shaw, Imperial Printing, p. 48, citing Gongshixubian, chap. 94, fol. 4a. Tsien Tsuen-hsuin, Paper and Printing, p. 216, citing Huidian, chap. 1199, fol. 1b. See also Jin Jian, Wuying dian juzhenban chengshi, fol. $\mathrm{b} / \mathbf{2 a}$, who comments that 'the yield was limited and the loss enormous' (suode youxian er suohao shenduo 所得有限而所耗甚多) when the copper types were melted down.

18 Lionel Giles, An Alphabetical Index, p. xvii, citing Wu Changyuan 吳長元 (fl. 1770), Chenyuan shilue 宸垣識略 (An outline of knowledge about [everything within the Peking] city walls, 1788). 19 Vogel, Chinese Central Monetary Policy, in sect. II.3 and III.1.c describes brass prohibitions, in 1673,1679 , and 1726-1736, but also several control measures against the melting down of coins and counterfeiting after the ban was officially lifted. Thus, in the years 1744-1745, when the Wuying dian types were melted down, hundreds of Peking brass manufacturers and dealers were ordered to move to workshops provided by the government where their trade would be supervised by officials.

20 For the year 1781 , about 655 strings were actually reported as cast from salvaged copper in the Peking mints. See Werner Burger, 'Minting', p. 383. 
and court administration try to save what could be saved before the types entirely disappeared from the storehouse? Or does this case show that although the printing project of the Gujin tushu jicheng was successfully finished, movable types made of copper were deemed too much of a luxury when wood, the more conventional printing material, would have served its purpose just as well? ${ }^{21}$

Another possible explanation that has so far not been discussed in the literature would be that at least part of the types were worn down and actually had to be recycled. Since one copy of the encyclopedia has about 100 million characters, after a print run of 64 copies, if each of the 250,000 types was used regularly (which is not probable); it would have been applied more than 25,000 times. It is more likely, however, that some of the types were used much more often and some rare ones were hardly taken out of the sorting cases at all. Cast lead types can be used for many more print runs before they are worn down. ${ }^{22}$ However, if the types used in this project were carved, and if what Christopher Reed concludes for tin types applies also for copper (de facto brass) types - namely that 'brushing' the paper onto the printing forms rather than 'pressing' it in a Gutenberg-style printing press wears down the types much sooner ${ }^{23}$ - then at least some of them may have been defect after the printing was completed.

At any rate, the technique of printing with metal movable type was successfully applied for a project of enormous dimensions, but thereafter its use was discontinued in the palace printery. There were certainly economic reasons that made the use of metal movable type seem wasteful: the process of typesetting - which involves finding the right characters in a set of ca. 25,000 different characters and sorting back the characters into the type cases after the printing was finished - rather than carving the printing blocks must have seemed too time-consuming. Moreover, the option of carving rather than casting types further slowed down the procedure and made it very costly. At the same time, manpower and storage space were abundant in the palace, and metal casting was a well-known everyday technology in the workshops of the central government, most prominently for casting cash. The Gujin tushu

21 The reverse case, when monetary metal was requisitioned for making type, occurred in 1910. From the mint of the Ministry of Revenue, Baoquanju 寶泉局, closed down in 1910, 977,500 jin ( 583.372 tons) of lead were requisitioned for the lead-type letterpress of the new ministerial printery. See Chen Zhen, Zhongguojindai, vol. 1, p. 318.

22 Typographus sinensis (W. H. Medhurst), 'Estimate', pp. 250-251, mentions that millions of tracts can be printed and the types used for twenty years without stopping, with a much smaller set of ten types where each has 3,00o different characters.

23 Reed, Gutenberg, pp. 66-67. 
jicheng project was neither the first nor the last where metal movable types were applied. The technology, which had first been developed in Korea, ${ }^{24}$, was re-invented in China and is associated with Hua Sui (1439-1513) from Wuxi in Jiangsu. It was first used in Jiangnan by several affluent families who intended to show themselves as sponsors of learning and printing. Later in the Ming dynasty, it was also used in the publishing centre Jianyang in Fujian for commercial printing, ${ }^{25}$ although the predominant technology remained woodblock printing. ${ }^{26}$ In the Ming, no printing projects with metal movable type of the court or central government are known at all. When the Qing court used this method, it still retained some of the flair of luxury that it had when the first Jiangnan families reprinted the rare works in their libraries in order to transmit knowledge and at the same time impress their peers. However, the Gujin tushujicheng project was neither the first nor the most voluminous imperial encyclopedia. Under the Ming dynasty, the even bigger Yongle encyclopedia (Yongle dadian) had been compiled but due to lack of funds was never printed, and the original manuscript was almost entirely lost by the end of the Ming. ${ }^{27}$ Thus, even if the Qing could not surpass their predecessors in terms of volume, they certainly achieved the printing of their imperial encyclopedia - and not in the conventional way but with an alternative technology that few people in the empire possessed - from the very material that cash was made of. This last fact may have been of some importance for the fate of the printing types after they had served their purpose.

The next outstanding project in Qing cultural policy that eventually also came to concern the Wuying dian printing office was the compilation of excellent and rare works extant in the eighteenth century. These were eventually combined to form the collectanea Siku quanshu (The complete books of the Four Storehouses [one each for the bibliographic categories cited above]). For this purpose, not only the books and manuscripts in the palace libraries but also those in the holdings of provincial authorities and private collectors were ordered to be sent to the capital - some for purchase, others on loan. In 1773, a commission of three-hundred officials and scholars was founded for collecting, classifying, and annotating - and, in the case of supposed or

24 See the discussion of several theories about the date of invention of metal movable types in Korea, from the earliest (1047-1083) to the date that is generally accepted (1232), 'The beginning of metal type printing', website of the Cheongju Early Printing Museum. The earliest book printed with metal movable types, the Buddhist commentary Jikji 直指 (Revelation of the deepest principles), printed in Chinese characters in Korea, is dated 1377.

25 Tsien Tsuen-hsuin, Paper and Printing, pp. 211-213.

26 Lucille Chia, Printing for Profit, p. 257.

27 Endymion Wilkinson, Chinese History, pp. 604-605. 
actual criticism of the dynasty or the emperors, also destroying ${ }^{28}$ - the books that were submitted from all parts of the empire. As a result, 10,246 titles were recorded in one extensive and one abridged bibliography. About 3,500 of these were transcribed eight times in handwriting, bound and stored in the Palace and in eight libraries built for that purpose. ${ }^{29}$

One spin-off of the project, however, kept not only the proofreaders and binders but also the character carvers of the Wuying dian busy during the 1770 s and 1780 s, producing one of the rarest Chinese handbooks of printing. The Ming encyclopedia Yongle dadian had been searched for entire works that had not been transmitted individually by the 1770s, and the result of this compilation - 138 reconstructed books - was printed by the Wuying dian printery between 1773 and 1794 in wooden movable type and included in the collectanea Wuying dian juzhenban shu (Wuying dian books [printed with] assorted gems). Jin Jian (or, having been of Korean ancestry, Kim Kan, deceased 1795), $3^{30}$ the Superintendent of the Wuying dian, directed the project. After having gained experience with the technical procedures, in 1777 he published the illustrated manual Wuying dian juzhenban chengshi (Patterns for printing with movable types at the [Imperial Printery] Hall of Martial Valour)..$^{11}$

28 See Kent Guy, The Emperor's Four Treasuries, pp. 166-2oo, for a general outline and specific cases of the so-called 'literary inquisition' of the Qianlong emperor in the 1770 s and 1780 s. This refers to a report of 1781 giving the figure of $5^{2,480}$ destroyed woodblocks for printing seditious books that had been broken up for firewood (p. 171).

29 Lu Shaw, Imperial Printing, p. 8, 49-50, Ciyuan vol. 4, p. 566: the libraries Wenyuan ge 文 源閣 on the precincts of the country palace Yuanmingyuan to the northwest of the capital; Wenyuan ge 文淵閣 in the Forbidden City; Wensu ge 文溯閣 in Shenyang; Wenjin ge 文津閣 in Rehe; Wenlan ge 文瀾閣 in Hangzhou; Wenhui ge in Yangzhou 文匯閣; and Wenzong ge 文 宗閣 in Zhenjiang. According to Lu Shaw, two manuscripts were stored in the Forbidden City at the Huangji Palace 皇極宮 and the Qianqing Palace 乾清宮. This would make a total of nine sets. Kent Guy, The Emperor's Four Treasuries, p. 104, defines as the first among the products of the Siku compilation project seven manuscript copies of the Siku quanshu.

30 For biographical information on Jin Jian, see Eminent Chinese of the Ch'ing Period, pp. 159-16o. One of Jin Jian's ancestors had joined the court of an early Manchu ruler, Hong Taiji 洪太極 (reg.1634-1643), as an interpreter. The family remained in the service of the Manchus. Jin's younger sister was a concubine of the Qianlong emperor and mother of three of Qianlong's sons. Therefore, the family was freed from the status of bondservants and became members of the Manchu Plain Yellow Banner. Between 1783 and 1792, Jin Jian served as Minister of Public Works ('President of the Board of Works') and thereafter of the Board of Civil Appointments (1792-95). As the Minister of Public Works he also directed several imperial building projects, such as the construction of the Imperial Lecture Hall Biyong 辟雍 in the Imperial Academy Guozijian 國子監(1785).

31 Union list 3-2-11. Translated by Richard Rudolph in A Chinese Printing Manual, and discussed and commented by Ernst Schierlitz, 'Zur Technik der Holztypendrucke'. Ironically, the handbook was printed with blocks. 
Together with the Yuan dynasty record that is included in the "Treatise on Agriculture' (Nongshu) by Wang Zhen (1290-1333), these are the only known technical descriptions of printing with wooden movable types. Even so, the written evidence for technical details of the movable type technology is better than that for block printing. This may be attributed to the fact that to gain financial support or to attract the reading public to special, more economic procedures for large printing projects, detailed justifications for the breach with established methods were necessary.

In his description of the methods of wood type printing, Jin Jian, while deploring the fact that the copper types of the Gujin tushujicheng were no longer stored at the Wuying dian, ${ }^{32}$ explains the shaping of all wooden parts of the printing process: the types, the sorting trays, the outlines and columns of the finished sheets that were not printed together with the movable type, the cases where the types were kept and the order in which they were stored, and the benches on which the typesetters stood in order to reach the higher drawers of the type cases. He also describes in detail the ten-day cycle of searching out the types from the type cases, setting them on forms, proofing the forms, printing, and re-distributing them into the cases (see Figures 20-22).33

Jin Jian also gave an estimate of the material costs of the project and pointed out that, by comparison, printing a copy of the 130-chapter Shiji (Memories of the Grand Historian) with the block printing method would entail the carving of 2,675 blocks for 1,450 tael. In a first estimate, he assumed that carving about 150,000 types of the most common six-thousand and several hundred characters including type blanks, type cases, setting forms, and other equipment would cost 1,40o tael. ${ }^{34}$ In his final account, he quotes a much higher figure of 235,000 types for a total material cost of 2,339.75 tael together with the wage quota of 0.69 tael for cutting one-hundred types. ${ }^{35}$ This would result in 22,425 tael for the entire set. Starting out with a staff of twelve, the number of workers and employees was eventually increased to one-hundred..$^{36}$

32 Jin Jian, Wuying dian juzhenban chengshi, fol. 1b/2a.

33 Ibid., fol. 31a-33b, transl. in Rudolph, A Chinese Printing Manual, p. 14.

34 Rudolph, A Chinese Printing Manual, p. xix, fol. 1b-2a

35 Ibid., p. xxi, fourth memorial dated from 1774 . These figures, including the wage quotations for cutting type blanks ( 0.22 tael per hundred), carving characters ( 0.45 tael), handwriting the characters to be carved ( 0.02 tael) are also specified in Huidian, chap. 1199, fol. 4b-5b.

36 Rudolph, A Chinese Printing Manual, p. xxii. Jin Jian, Wuying dian juzhenban chengshi, 'Zouyi' (Memorials), fol. 1ob/11a. 
Figure 20 Sawing the wooden types

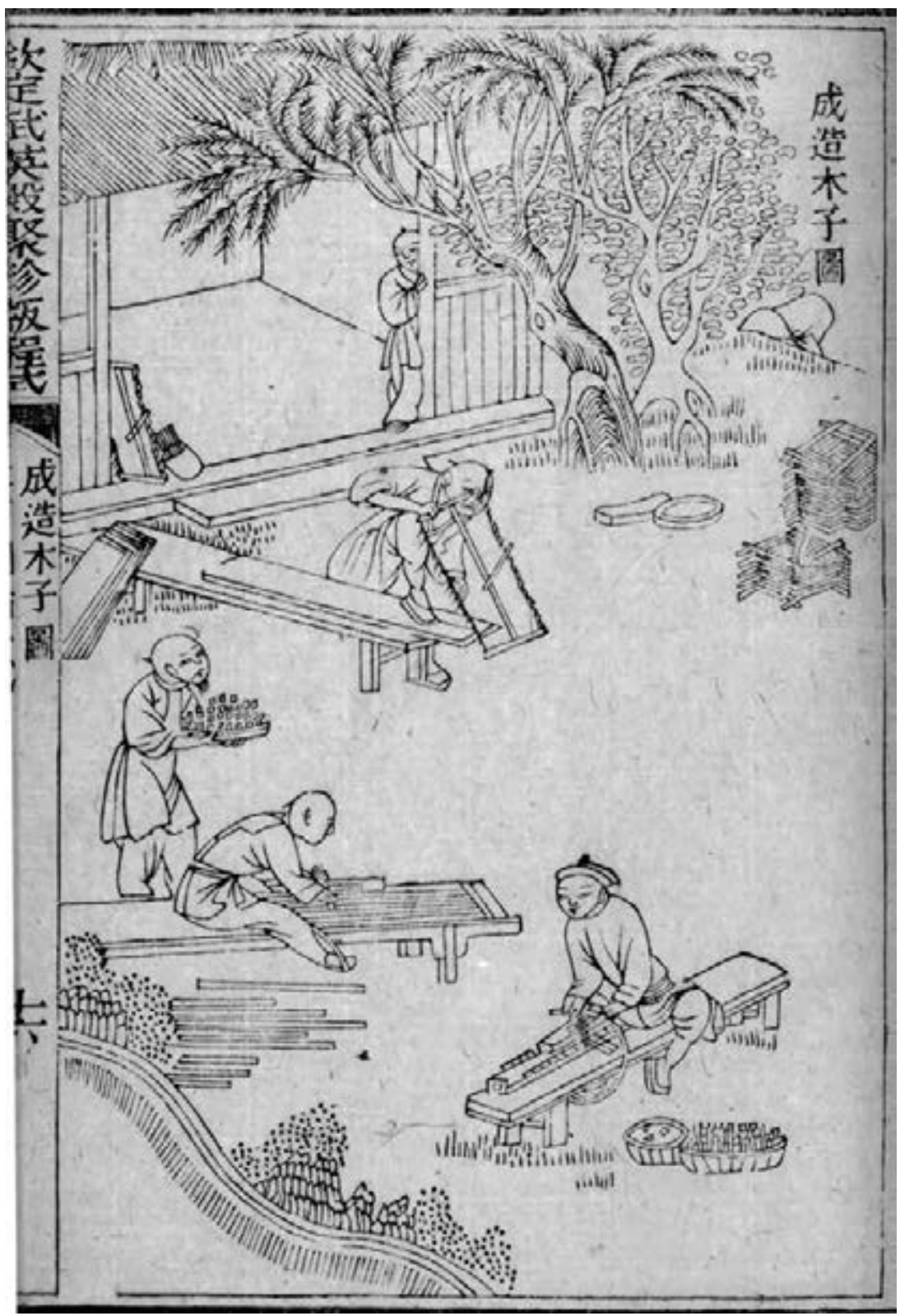

Source: Jin Jian, Wuying dian juzhenban chengshi, fol. 16a. 
Figure 21 Carving the types

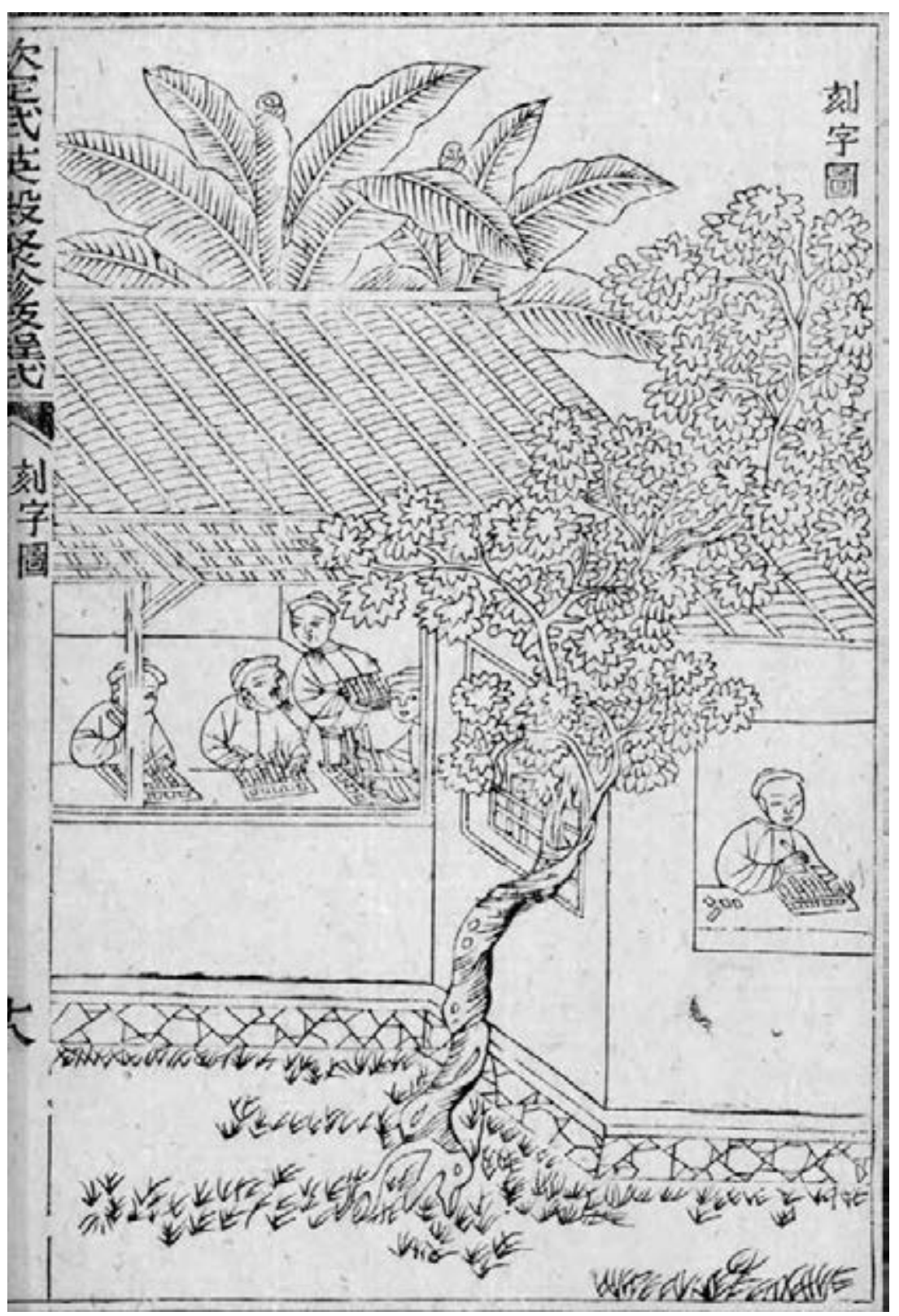

Source: Jin Jian, Wuying dian juzhenban chengshi, fol. 18a. 
Figure 22 Type setting. This process includes selection of the types from the type cases, placing them on trays, arranging them in the right sequence, and proofing the set forms.

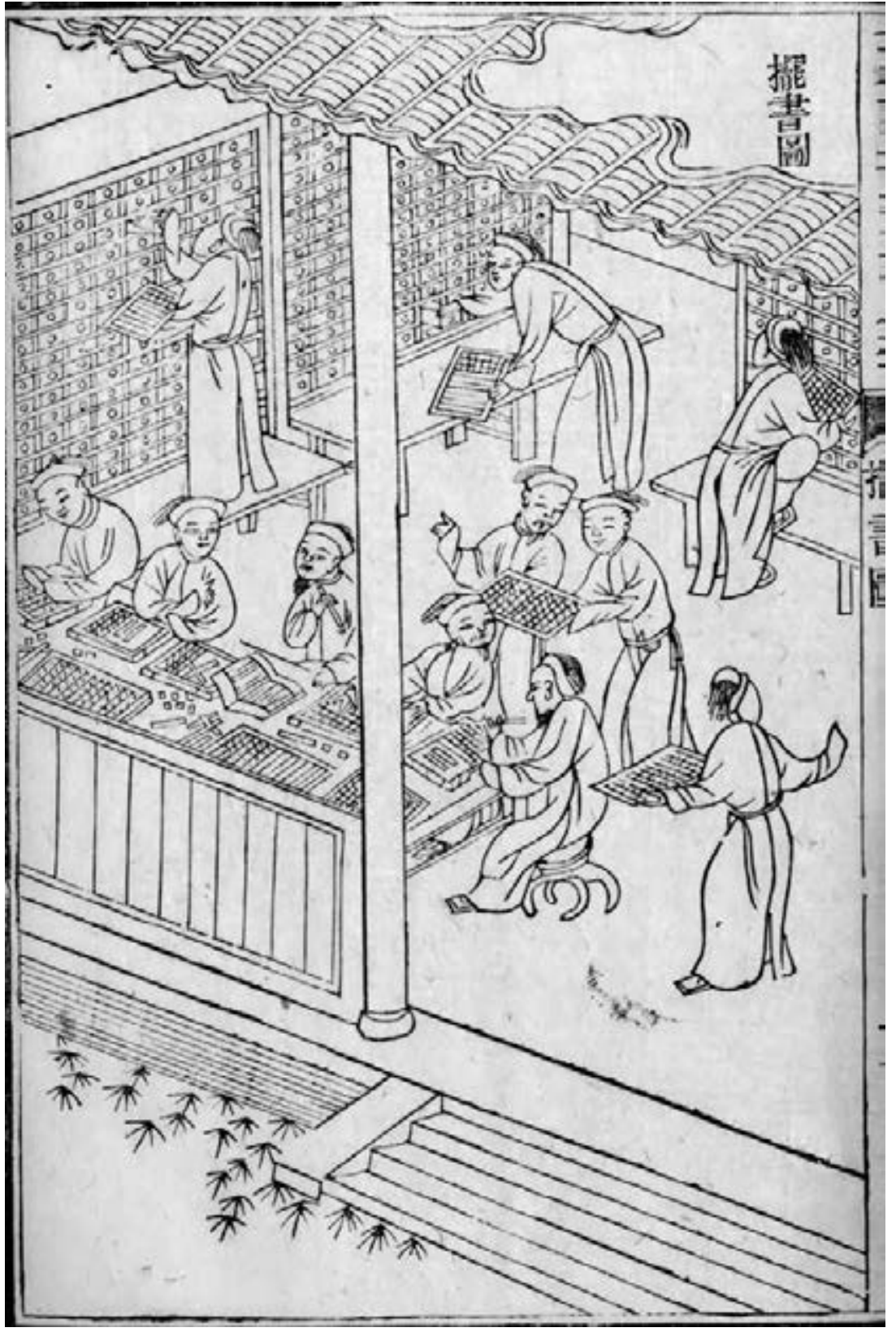

Source: Jin Jian, Wuying dian juzhenban chengshi, fol. 28b. 
Figure 23 Individual wooden movable types in different sizes at the Gutenberg Museum, Mainz, dating about 1860

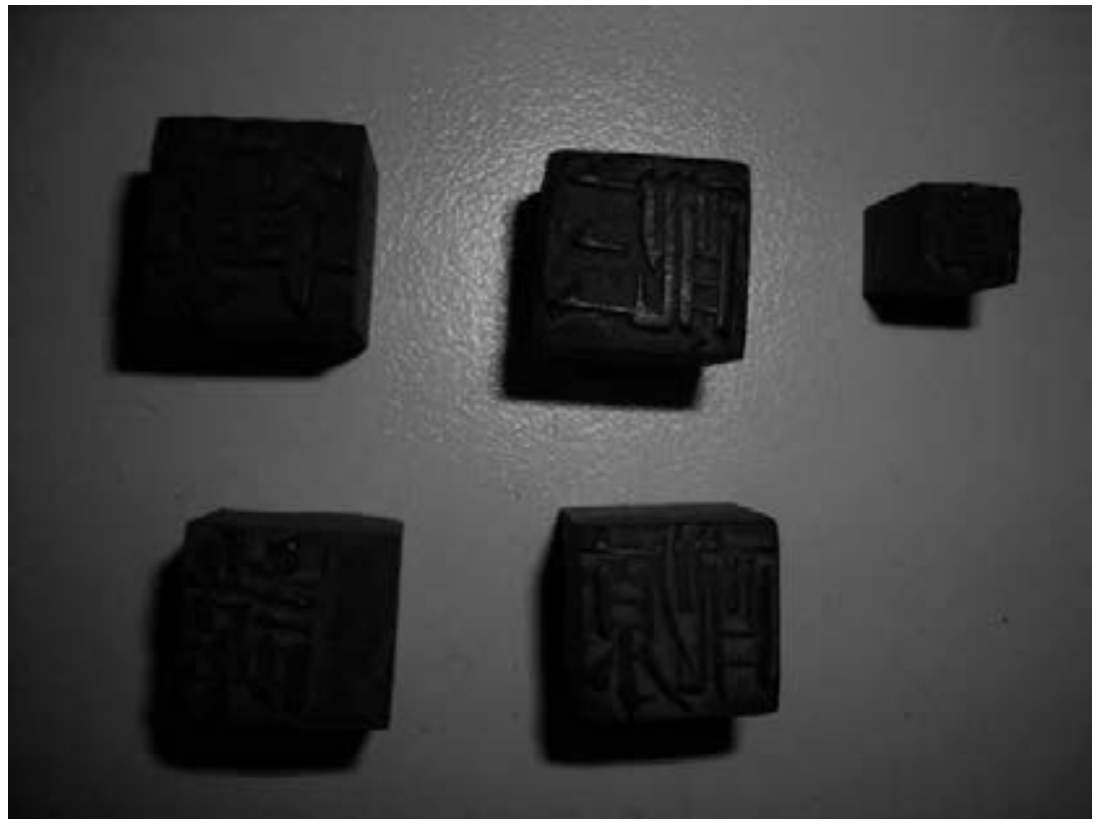

According to the memorials in the preface of the Wuying dianjuzhenban chengshi, the collectanea were printed in twenty sets upon white fourfold paper liansizhi for court display and preservation, and several more ${ }^{37}$ on yellow bamboo paper zhuzhi to be sold at a fixed price. ${ }^{38}$ Provincial and private printeries were expressly authorized to reprint selected items of these exemplars or of the entire set, which they did in Jiangsu, Jiangxi, Zhejiang, Fujian, and Guangdong. The Jiangxi and Fujian reprints were especially complete and true to the originals. ${ }^{39}$ The reprints, as far as can be judged from the extant copies, were done with block prints rather than movable type. ${ }^{40}$ According to Schierlitz, in 1792 the types were copied in Korea in a set of 320,000 . Here, they were referred to as 'continuously renewed types' (shengsheng zi). ${ }^{41}$

37 According to Lu Shaw, Imperial Printing, p. 57, 'three hundred sets were printed on bamboo paper for public consumption.'

38 Jin Jian, Wuying dian juzhenban chengshi, 'Zouyi' (Memorials), fol. 6a.

39 Lu Shaw, Imperial Printing, p. 58; Schierlitz, 'Zur Technik', p. 36.

40 It is not easy to discern the difference between imprints with movable type and block prints.

41 Schierlitz, 'Zur Technik', pp. 36/37. 
Shiow-jyu Lu Shaw lists six further individual titles that were printed with this set but states that later the entire set was destroyed by custodians and burned as firewood..$^{42}$ In fact, they were probably not destroyed in the fires at the Wuying dian in 1869 and 1901 because they were kept in an external storehouse. The entire workshop for typesetting and printing was situated not in the Wuying dian but at a branch office in the Bei changjie Street near the Xihua men palace gate. ${ }^{43}$ Schierlitz reports that a Chinese eyewitness saw wooden types on sale in Peking after the revolution of 1911. These may have been remnants of the 'assembled gems', but since at least one other private printery in Peking also used wooden movable type, the whereabouts of Jin Jian's types remains uncertain (see Figures 23-25 for a set of wooden movable types).

Nevertheless, it becomes clear from these two large projects that although the palace printery was innovative in developing alternative printing technologies and even published a kind of 'user manual', the use of printing with either metal or wooden movable type actually remained quite limited.

\section{Provincial Printeries}

After the mid-nineteenth century, the provinces and provincial elites gained greater independence from the central government than was the case in the eighteenth century. In the course of these political shifts, the printing facilities of the provincial printeries increased in size.

In the late seventeenth and early eighteenth century, an official printery was established at Yangzhou, the so-called Yangzhou shiju (Yangzhou Poetry Office), which was supervised by the eminent and affluent Cao Yin (1658-1712), a bondservant of the Manchus who had also been in charge of the Imperial Silk Weaveries in Nanjing (1693-1712) and concurrently acted as salt censor of the Liang-Huai circuit in 1704, 1706, 1708, and 1710. ${ }^{44}$ Since Cao Yin's connection to the Imperial Household was particularly close, many printing projects were entrusted to him, such as the 9oo-chapter Complete poetry of the Tang dynasty or several smaller-sized encyclopedias. As such, this institution stood between the central government and the purely provincial institutions. The output of the Yangzhou Poetry Office amounted to about 3,000 
Figures 24 and 25 Types on the tray, Gutenberg Museum
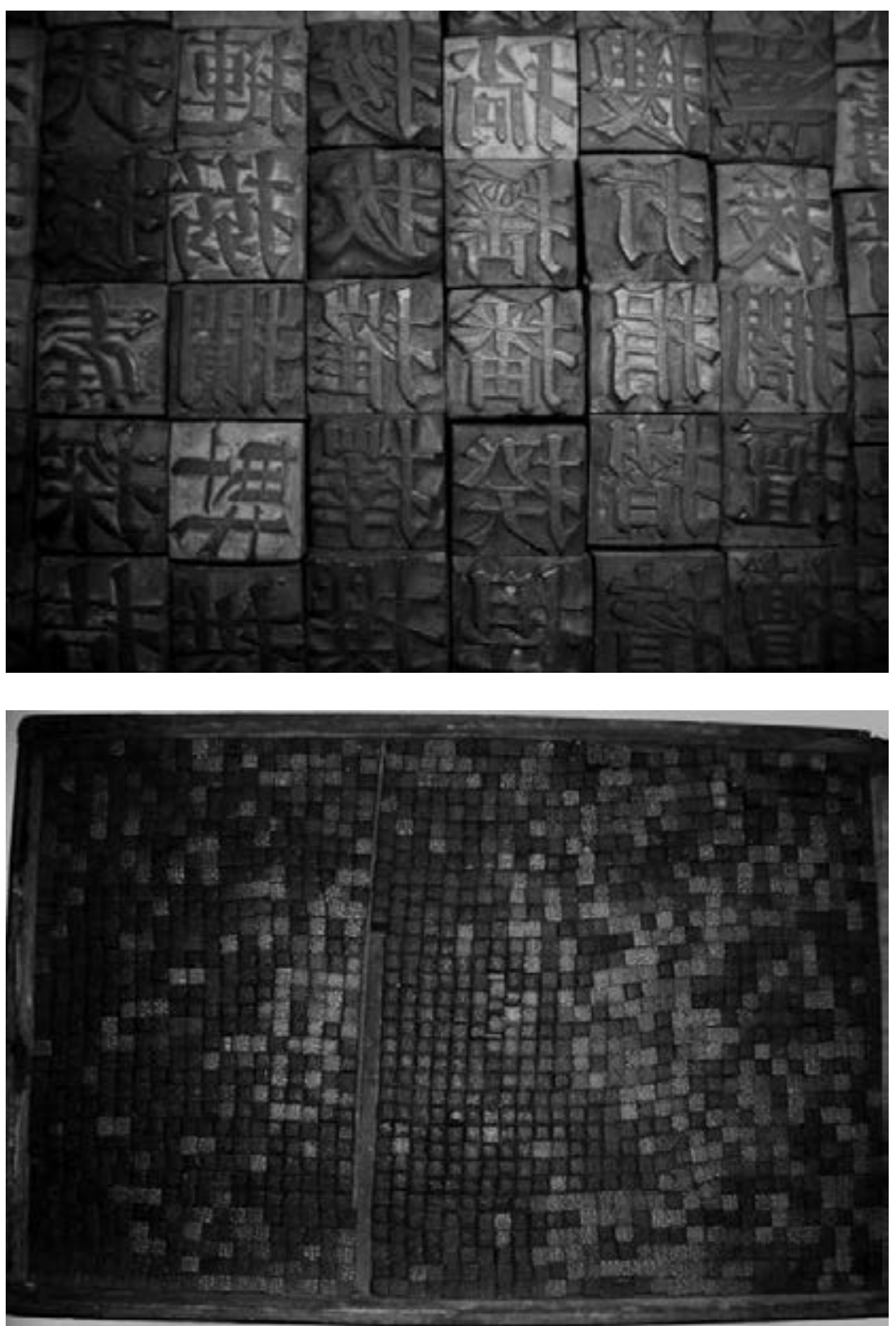

Source: Author's photographs, August 2008. Courtesy of the Gutenberg-Museum. 
chapters. They were executed as block printings of very high quality in the cherished and expensive 'soft style' of printing. This is a generic designation for the 'handwriting' or 'calligrapher's' style. Since the width of vertical and horizontal lines is more evenly distributed, this resembles calligraphy more than the 'hard style' or 'Song type', also referred to as the 'artisan style' (jiangti). Carving the soft style takes longer and requires greater skill. The 'artisan style' (jiangti 匠体) with strong vertical and light horizontal lines became widespread during the late Ming, as the printing industry expanded. ${ }^{45}$

Provincial governments already possessed printing facilities in the seventeenth and eighteenth centuries. For instance, the 1769 'Regulations and precedents on the prices of materials' (Wuliao jiazhi zeli) were printed separately for each province, presumably at the provincial government office. Confucian schools that were maintained by local and regional administrations often organized printing activities, as many regional gazetteers suggest. ${ }^{46}$ After the Opium War and the Taiping rebellion, most provinces established provincial printeries more formally and prominently with funds of their own. They clearly had the order to reprint works that had gotten lost in the turmoil. The lack of texts of the Confucian state orthodoxy was especially felt in the Jiangnan area, where of the three libraries that had been specifically built for housing the apex of knowledge contained in the Siku quanshu, two (at Yangzhou and Zhenjiang) were completely destroyed, and one (in Hangzhou) was damaged. Book historians are not quite clear as to whether the main impulse came from the central government or from the provinces. While Zhang Xiumin vaguely refers to 'the ruling classes' who established provincial publishing houses with printeries (guan shuju) 'in order to restore the old order, ${ }^{\prime} 7$ more recent publications specifically stress the role of the provincial governments and provincial elites, most of all Zeng Guofan, one of the central figures of the self-strengthening reforms. ${ }^{48}$ Likewise, while Zhang Shudong presents the Yangzhou shiju as one of the first provincial

45 'Plurality of Printing Techniques' Website of the Palace Museum, Taibei, Taiwan.

46 See [Qianlong] Hangzhou fuzhi j. 10, fol. 17a, referring to the carving and printing of the Kangxi emperor's Sacred Edict; or [Qianlong] Dushan zhouzhi, 'Baoming xiuji zhishu shenwen' 報明修輯志書申文 (Declaration on the compilation and editing of [this] gazetteer), fol. 1b/2a. The literature on gazetteer compilation amply discusses the issue, see for instance Li Jingwen, 'Qingdai Henan shuyuan keshu qianlun', p. 102, and Zhang Andong 'Qingdai xiuzhi jigou de renyuan shezhi he ziliao laiyuan', p. $5^{\circ}$.

47 Zhang Xiumin, Zhongguo yinshua shi, pp. 559/560.

48 Zhang Shudong, Zhongguo yinshua, chap. 7, Sect. 6-5, (5), 1. (3) 地方官書局刻書; Qingdai yinshua, 'Qingdai de difang zhengfu yinshua' 清代的地方政府印刷. Qingdaiyinshua is obviously an abbreviated form of Zhang Shudong's account. 
printeries, Zhang Xiumin does not discuss continuity but rather stresses the difference between the Kangxi era and the mid-nineteenth century. ${ }^{49}$

The evaluation of the achievements of these provincial offices varies as well. Tsien Tsuen-hsuin states in a general sense that 'all were renowned for careful execution and mutual co-operation', $5^{\circ}$ but Zhang Xiumin and especially Zhang Shudong discuss in more detail the achievements and failures of the print products of these institutions. The scholars agree, however, that among the twenty offices listed (see Table 31), the Zhejiang and the Guangdong printeries had the greatest output. Thus, an account of 1935 gives the number of printing blocks that were still extant from the Qing as 122,000 carved at the Zhejiang office and an additional 39,00o that had been presented or deposed there by private collectors and printers, such as Ding Bing (1832-1899) from Hangzhou and Hu Fengdan from Jinhua. The number of printing blocks in the Guangya shuju and two Guangdong academies amounted to a total of 150,000 to $160,000 .{ }^{11}$ However, not all imprints were carved in blocks. The Jinling and the Jiangxi official printeries also used wooden movable type, and the Yunnan and Zhejiang office had a lead letterpress. Since luxury and ornamental editions were not usually in the product range of the official printeries, few multicoloured prints (taoyin) were produced; merely a few specimens are reported from Hubei and Zhejiang..$^{2}$

On the basis of bibliographies of the provincial printeries, Zhang Xiumin estimates that their aggregate book production was about 1,00o titles. All four categories of Chinese bibliography were included, but most of their books belonged to the fields of classics and history, especially the dynastic histories. ${ }^{53}$ In addition to this, books dealing with 'modern' topics like telegraphy or documented recent treaties with foreign countries were also printed. ${ }^{54}$

The main government printing activities thus spread from the central government to the provinces, as is clear from the approximate data of 36 'palace editions' (dianben) against about one-thousand '[provincial printing] office editions' (juben) between 1862 and the end of the dynasty. The reason

49 In his book length study on Cao Yin, Jonathan Spence discusses Cao's efforts and achievements in the printing of the 'Complete Poems of the Tang', but although he elaborates on the other institutions which Cao directed, the Nanjing Imperial Silk Weavery and the Liang Huai Salt Commissioner's office, he mentions the printery not as an institution but rather as an ad hoc commission for one specific project - albeit one that earned Cao Yin great honours. Spence, Ts'ao Yin, pp. 164-165.

50 Tsien Tsuen-hsuin, Paper and Printing, p. 188.

$5^{1}$ Zhang Xiumin, Zhongguo yinshua shi, p. 564.

$5^{2}$ Ibid., p. 564 .

53 Zhang Xiumin, Zhongguo yinshua shi, p. 563

54 Ibid., p. 563. These titles are all from the Zhejiang office. 
for this situation was most probably the central government's lack of funds. It is no wonder, then, that the regions with the most collectors who showed interest in supporting the official printing offices with either printing blocks or exemplars, such as Ding Bing, or with active fund-raising officials, such as Zhang Zhidong in Guangdong, had the largest facilities and the greatest output.

Nevertheless, the central government did not completely avoid modernization in the printing sector in terms of contents, technology, and equipment. Modern government schools such as the Peking Tongwen guan (basically a school for translators and interpreters that had branches in Shanghai and Canton) and the research departments of the Jiangnan Arsenal and the Fujian Navy Yard all had their own printeries. Both the Peking Tongwen guan and the Jiangnan Arsenal publishing departments printed about 200 translated works respectively. The Jiangnan Arsenal print shop at first (in 1868) only carved woodblocks, but in about 1875 installed its first lead type letterpress machine. It was later taken over by the Shanghai Official Printing Office. 55 The Tongwen guan press, which was established in 1876 (or 1873), ${ }^{56}$ also printed internal documents, edicts, and announcements and had seven hand letterpresses and four sets of Chinese types. In 1884, government publications were also printed in the newly founded Xiehua shuju that possessed modern printing machinery. In 1905, it was taken over by the commercial publisher Shangwu yinshuguan and had its name changed to Jinghua yinshuju. At first, it had about twenty to thirty employees and only letterpress machines, but later colour presses and lithographic machines were added. Another modern printing facility in Peking was the 'Zhili official printing bureau' (Zhili guan shuju), which was also named the 'Metropolitan official publishing bureau' (Jingshi guan shuju) ${ }^{57}$ Its foundation is attributed to General Yuan Shikai (1859-1916), who was a provincial judge in Zhili province between 1897 and 1899. Its exact date of establishment cannot be ascertained, but the thirteen extant editions in the National Library of China, all lithographs or typeset, date from the Guangxu reign, with the last from 1907. In terms of content, these were administrative documents of a more general interest, such as the 'Collected Statutes' in one-hundred chapters but without the voluminous 'Factual Precedents' (in 1,220 chapters). Since the Collected Statutes had previously

56 Bai Shouyi, Zhongguo tongshi, vol. 11, chap. 18, sect. 2, 'Zhongguo jindai chuban shiye de zhubu fazhan' 中国近代出版事业的逐步发展 (The gradual development of the modern Chinese publishing sector).

57 Bai Shouyi, Zhongguo tongshi, vol. 11, chap. 18, sect. 2, 'Chuantong keshuye de fazhan' 传统 刻书业的发展 (The development of traditional character carving). 
been published in Shanghai, and in view of its other publications which are all much shorter, this printery apparently was not a very large institution.

After the administrative reforms of 1905, both the Ministry of Education (1906) and the Ministry of Finance (1907) established their own printing offices. The Ministry of Education printed textbooks at its Xuebu tushuju, while the Ministry of Finance, which had invested large sums and acquired the newest Western technology, produced paper money and other financial documents at the Duzhi buyinshua ju.

In sum, the modern printeries of the capital that had been founded and financed in part or entirely by the central government until the last decade of the Qing rule remained smaller in scope and more specialized than the Wuying dian had been, and neither the printery of the Jiangnan Arsenal nor the Zhili provincial printing office were entirely under the control of the court and central government.

These developments illustrate the general shift of political power from the Peking central government to the affluent Jiangnan and Guangdong centres as well as the North Chinese military faction around Yuan Shikai and Li Hongzhang. Within Peking, they also show the diversification of printing institutions, which no longer came under the direct and personal control of the emperors or the regents.

\section{Periodical Government Publications of the Nineteenth and Twentieth Centuries: Court Gazettes and Provincial Newspapers}

One of the government printing products, although published in the capital and pertaining to the Qing court, was not at all a luxury or exemplary item but aimed to inform a broader reading public beyond the directly concerned officials in the affairs of the court and the central government. Government news had been spread in short bulletins since the Song dynasty. The earliest extant examples date from the Ming. In the Qing, the so-called dichao (liaison officials' transcripts), jingchao (capital transcripts), gongmen chao (palace gate transcripts), and jingbao (capital reports) were copied, printed, and distributed to the provinces by the 'newspaper workshops' (baofang) of the postal relay stations (titang) in the Peking publishing and bookselling centre Liuli chang. These gazettes contained edicts, memorials, and reports that had been released by the Grand Secretariat..$^{8}$ Sixteen of the relay stations existed in Peking, assigned for delivery to and from Zhili, Shandong, Shanxi, 
Henan, Jiangnan, Jiangxi, Fujian, Zhejiang, Hubei, Hunan, Shaanxi and Gansu, Sichuan, Guangdong, Guangxi, Yunnan, and Guizhou. A foreign observer in the late Qing assumed that the printing was done in only one of the relay stations, ${ }^{59}$ while another source hints that the gazette was issued by twelve publishing houses and distributed at a rate of ten-thousand copies per day. ${ }^{60}$ The official copies were printed with wooden movable type; unofficial, faster copies were either handcopied or printed with wax plates. ${ }^{61}$ Zhang Shudong also refers to yet another method of fast duplication, the so-called 'dried doufu plates' (dougan'er ban), and a kind of fast hardening plaster which was burned after the characters were carved. In both cases, the non-printing parts of the plate were carved out as in wood block carving. Their quality was very low, but these methods were cheaper than the handcopied versions and faster than the wooden type versions. ${ }^{62}$ In the provinces, the court gazettes were once again reprinted and distributed. Circulars that contained only information from provincial authorities were referred to as yuanmen chao or yuanmen bao (transcripts or reports from the provincial government gates). The printing, most often with wax plates, and distribution of these provincial gazettes was handled entirely by the private sector. ${ }^{63}$

The court gazette was published until 1911 but declined in the last years of the dynasty. This may have been due to the competition from the private press that had emerged in the treaty ports, most of all in Shanghai. However, as Vittinghoff argues, the decline was perhaps more linked to the challenge from so-called 'official newspapers' (guanbao or gongbao), which regional administrators published after private newspapers had been forbidden in 1898. ${ }^{64}$ Like the provincial printeries, and sometimes together with them, such official newspapers were founded in most provinces. ${ }^{65}$ The most famous

59 Ibid., referring to Mayers, 'The Peking Gazette', p. 15.

60 Ibid., p. 57.

61 For a detailed description of the various unofficial formats and versions of the court gazettes, see Barbara Mittler, A Newspaper for China, pp. 179-187.

62 Mayers, 'The Peking Gazette', p. 16. Mayers quotes the following subscription prices for the copies of the Peking Gazette: 25 cents per month for natives, somewhat more for Europeans; about the same sum or slightly more for the official (post relay) version, but five taels per month for the handcopied version. The Gazette was also reprinted in the modern treaty port journals, such as Shenbao (1872-1949) and Shanghai Xinbao (1861-1872); see Janku, Nur leere Reden, p. 65, 171. Moreover, it was translated into English in the Shanghai based journal North China Herald.

63 Zhang Shudong, Zhongguo yinshua, chap. 7, sect. 3; Vittinghoff, Anfänge, p. $5^{8 .}$

64 Vittinghoff, Anfänge, p. $5^{8 .}$

65 For a list of official printing institutions of the late Qing, including the official newspapers, see Zhang Shudong, Zhongguo yinshua, chap. 14, sect. 1, table 14-2 'Guanyin, guanbao deng qita guanban yinshua jigou yilan biao’ 官印、官报等其它官办印刷机构一览表 (Overview of official printeries, official journals and other official printing institutions). 
among these were Shandong Governor-General Yuan Shikai's Beiyang guanbao (North China Official Newspaper, established in 1902) and Hu-Guang Governor-General Zhang Zhidong's Hubei guanbao (established in 1898). ${ }^{66}$

Nevertheless, government institutions continued to supply daily court information until the end of the dynasty. The very last of the 'modern' printing institutions founded under the Qing dynasty were the facilities of the Imperial Household Department which were installed to print the long-established court gazette gongmen chao with lead type letterpress. ${ }^{67}$

\section{Paper Money in the Nineteenth and Twentieth Centuries}

Although the use of paper money and official bills of exchange was first recorded in the Song dynasty and the system was continued for longer or shorter periods during the Yuan and Ming, the Qing only adopted it as a method of last recourse in situations of extreme scarcity of monetary metal. This occurred during one decade in the early years of the dynasty (1651-1661), but thereafter, for a lapse of almost two hundred years, no paper money was printed by the government. ${ }^{68}$ It was only in 1853 , during the Taiping rebellion, that the Qing issued bank notes denominated in cash, the so-called Great Qing treasure notes (Da Qing baochao), and in silver, the Ministry of Revenue official notes (Hubu guanpiao). The cash notes were denominated from between 500 and 1 million cash, and the silver notes from between one and 50 taels. ${ }^{69}$ We can only estimate how many single notes were issued. Frank King quotes a figure of over 15 million (ching-)ch'uan (cash strings) in Peking alone, not considering the provinces; ${ }^{70} \mathrm{Zhang}$ and Tan assume that the total figure may have been 9.78 million of silver tael and 27.11 million cash string notes; in 1868, only 3.28 million silver tael notes were reportedly retrieved. The rest may have been destroyed in the Taiping rebellion or hoarded, as in a case described by Zhang and Tan..$^{1}$

In Peking, the silver notes were issued directly by the Ministry of Revenue and the cash notes through official banks. ${ }^{72}$ As in the Song dynasty, the ministry or its agents printed the notes either with wooden or copper blocks.

66 Vittinghoff, Anfänge, p. $5^{8 .}$

67 Zhang Shudong, Zhongguo yinshua, chap. 14, sect. 1, table 14-2.

68 Peng Xinwei, Monetary History, p. 707.

69 King, Money, p. 15 o.

70 Ibid.

71 Zhang and Tan, 'Xin faxian', section 4.

72 King, Money, p. 150. 
The ornamental, relatively simple two or three colour prints resembled those of the Ming dynasty notes. Counterfeiting was not difficult. In order to prevent it, the issuing institutions stamped the notes with official seals. Apparently, the Ministry also delivered blank notes to the provincial governments which would later print out the denomination. ${ }^{73}$

The experiment was not considered a success, and the notes were withdrawn by 1872 . Privately issued drafts, silver bills by pawnbrokers, cash bills, and foreign notes nevertheless continued to be used, and the central government did not (and could not) restrict their circulation. After the Sino-Japanese War, the provincial governments started to issue their own bills, such as the North China Railroad Official Track General Office (Beiyang tieguiguanlu zongju ) in 1895, or the Hubei and Guangdong provincial administrations in 1899. The Beiyang Railroad bills were printed in London and the Hu-Guang bills by the Japanese Treasury Department. ${ }^{74}$ The Railroad bill was produced in the 'modern', horizontal format, but the Hu-Guang bill retained the traditional vertical format. Taiwanese banknotes were issued by the Tainan Official Silver and Cash Bill General Office after the island had become a Japanese colony in $1895 .^{75}$

After the reorganization of the central government and its ministries in 1904, the new Ministry of Finance (duzhi bu) considered printing paper money again. At first, the Ministry investigated the options for outsourcing. The Beiyang Official Newspaper Office, the Japanese Treasury Department, and the Commercial Press in Shanghai all had the skilled labour and know-how in machinery and technical processes and could have fulfilled the commission, but in the end the Ministry established a printery of its own for paper money, stamps, tax seals, and other financial documents and entrusted the acquisition of machinery and technology transfer to the American Banknote Company. The printing office was founded in 1907, and two specialists from the American Banknote Company were invited to teach Western methods of steel-plate intaglio printing to the Chinese printers and engravers..$^{6}$ The central government invested a total of 1.1 million tael to set up a modern factory in Peking outside the city gate Xuanwu men on an area

73 Zhang and Tan, 'Xin faxian', from a sample of 267 notes in eleven denominations have made out eight different block (or stamp) types for the characters on same denomination silver notes, and the cash notes also showed differences. In some cases, the figures were handwritten, as on a 1859 five tael note auctioned in November 2013. See the website of the auction house Chengxuan, '2013 qiuji paimai hui. Zhibi’ Lot 2342.

74 Peng Xinwei, Monetary History, pp. 711-712.

75 Ibid., p. 712 .

76 Reed, Gutenberg, p. 65; Zhongguo yinshua tongshi, chap. 17, sect. 3 . 
of 240,000 square metres (see Figure 26). Architectural firms from Japan and the United States (Milburn, Heister \& Company) were entrusted with the construction, which was finished only in 1914, after the demise of the Qing dynasty.77 The newest machines for steel-plate gravure, lithographic, and letterpress printing as well as photographic devices and power engines were imported from the United States in order to guarantee the production of high-quality bank notes.

One of the first model banknotes of the 'Great Qing Bank', a onehundred silver dollar (yinyuan) bill showing a large portrait of the regent Zaifeng (1883-1851), the father of the last emperor, was designed by the American illustrator Lorenzo J. Hatch (d. 1913) of the American Banknote Company. It was finished in 1910, and on the first day of the third month of the year 1911, regular printing production was started..$^{8}$ The investment of the Qing government in modern printing machinery, technology, and knowledge transfer lasted longer than the dynasty. After the fall of the Qing, the American experts stayed on and continued to train Chinese printers and designers. In 1915, the products of the printery of the Ministry of Finance won an award at the Panama Pacific International Exposition. ${ }^{79}$

\section{Conclusion}

In considering the three fields of government printing discussed above - the reproduction and augmentation of traditional learning with books, the printing of information on actual court events and decisions, and the

77 Chen Zhen, Zhongguo jindai, ‘Beijing duzhibu yinshuaju’ 北京度支部印刷局 (The Printing Office of the Peking Ministry of Finance), pp. 319-320. Milburn, Heister and Company, Selections from the Latest Works of Milburn, Heister \& Co., p. [28]; Specifications for a Bureau of Engraving and Printing for the Chinese Government to be erected in Peking. According to 'Commerce: The Chinese Bureau of Engraving and Printing', at present the main building houses one part of the China Banknote Printing and Minting Corporation.

78 According to Zhang Shudong, chap. 17, sect. 3, this day was declared the 'banknote printing memorial day' (chaopiao yinshua jinianri 钞票印刷纪念日). Peng Xinwei, while affirming the high quality of the paper money printed with modern machines, is sceptical whether much of it was actually used, since most of the banknotes he had seen were model notes (p. 713). More specifically, an anonymous article published on the website Gu qianbi shoucang wang 古钱币收 藏网 ('Old money collector's web', dated 2004-10-16, accessed Sept. 2007) declares that although Hatch's design was superb, the banknote could not be circulated because the dynasty fell soon after it was finished. See 'Zhibi de jianding he bianwei' 纸币的鉴定和辨伪 (Assessing paper money and forgeries).

79 Zhang Shudong, Zhongguo yinshua, chap. 17, sect. 3. 


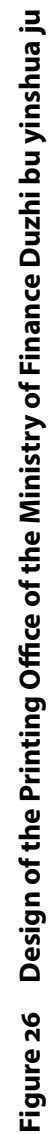

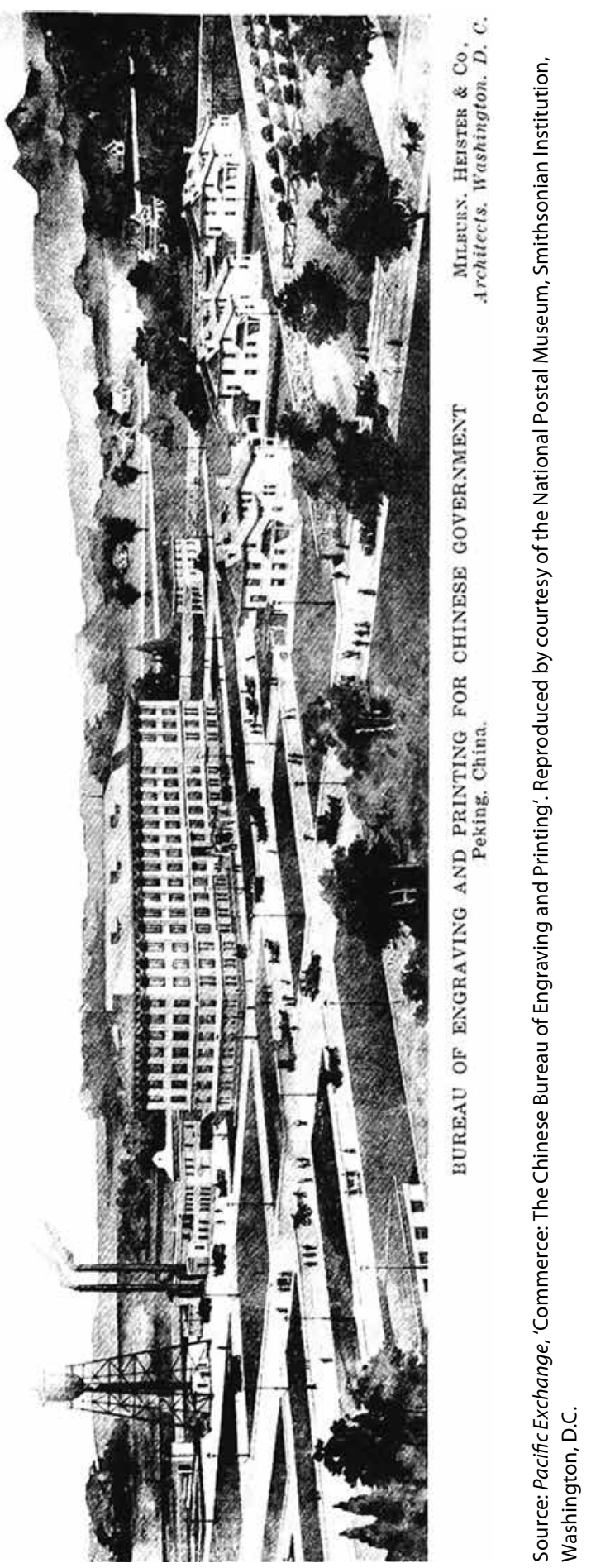


production of financial documents - the Qing central government placed the highest importance on the first for much of its reign, experiencing an apex in the eighteenth century. The Qing continued to supply information on court events and decisions but only hesitantly engaged in the production of financial documents, and only in the last moment. Provincial governments took the lead after the mid-nineteenth century, replacing or complementing the printing activities of the centre. In the case of the currency, however, the Qing government tried to reassume its leading role and unify the multiple notes and bills in circulation at the time in an attempt to stimulate technology transfer from the West and, to some extent, Japan. It was not a technical problem that stood in the way here.

\section{Appendix}

Table 32 Estimate of the mass of cash coins to be retrieved from 250,000 copper types used in the printing project for the imperial encyclopedia Gujin tushu jicheng (1726-1728)

\begin{tabular}{|c|c|}
\hline $\begin{array}{l}\text { Size of Gujin tushu jicheng types on } \\
\text { the imprints }\end{array}$ & $\begin{array}{l}\text { ca. } 1 \mathrm{~cm} \times 1 \mathrm{~cm} \text { for regular characters, } 0.5 \mathrm{~cm} \times 1 \mathrm{~cm} \\
\text { for half width commentary size characters }{ }^{1}\end{array}$ \\
\hline Standard weight of one copper cash & 2.98 to $4.48 \mathrm{~g}^{2}$ \\
\hline Estimated weight of one copper type & $\begin{array}{l}\text { Ca. three times that of a copper cash, that is } 8.94 \\
\text { to } 13.44 \mathrm{~g}^{3}\end{array}$ \\
\hline Estimated weight of 250,000 types & 2,235 to $3,360 \mathrm{~kg}$ \\
\hline Weight of one string of 1,000 cash & 2.98 to $4.48 \mathrm{~kg}$ \\
\hline $\begin{array}{l}\text { Estimated yield of } 250,000 \text { types in } \\
\text { strings }\end{array}$ & 750 strings if one type yields three copper cash \\
\hline Alloy of types & Unknown \\
\hline Alloy of cash & ca. $50 \%$ copper, $41.5 \%$ zinc, $6.5 \%$ lead, and $2 \%$ tin \\
\hline Alloys of Korean metal types & $\begin{array}{l}\text { Bok type in Korean National Museum: } 50.9 \% \\
\text { copper, } 0.7 \% \text { zinc, } 28.5 \% \text { tin, } 10.2 \% \text { lead, } 2.2 \% \text { iron }^{4} \\
\text { 'General value': copper, tin, and zinc in the ratio } \\
\text { of 7:2:1 ('ancient times'), general proportion of } \\
\text { bronze: 70\% 95\% copper, 5\% 30\% tin. }\end{array}$ \\
\hline $\begin{array}{l}\text { Conclusion for the conversion of type } \\
\text { into cash }\end{array}$ & $\begin{array}{l}\text { The copper content shouldn't be a problem, if the } \\
\text { content of tin can be adjusted accordingly. }\end{array}$ \\
\hline For comparison & $\begin{array}{l}\text { In } 1781,655 \text { strings and } 200 \text { cash were cast from } \\
\text { salvaged copper in the Peking mints. }{ }^{6}\end{array}$ \\
\hline \multicolumn{2}{|c|}{ Wear and tear of the types during the 64 print runs } \\
\hline $\begin{array}{l}\text { Number of characters of one set of } \\
\text { Gujin tushu jicheng }\end{array}$ & ca. $100,000,000$ \\
\hline Number of types & ca. 250,000 \\
\hline
\end{tabular}




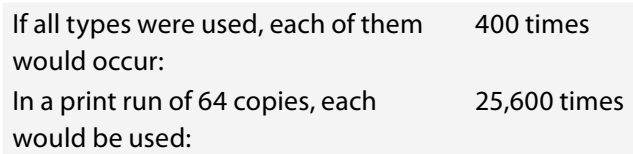

1 Lu Shaw, Imperial Printing, p. 47, however, mentions $0.5 \times 0.5 \mathrm{~cm}$ for the commentary size. This can hardly be the case, since commentary characters had the same height as regular ones.

2 Burger, 'Minting', p. 378, 383.

3 The regular (not commentary) size Korean bronze types in the Gutenberg-Museum Mainz weigh between 10 and 15 grams. My thanks to Director Dr. Eva-Maria Hanebutt-Benz for the information. 4 Cheongju Early Printing Museum, 'Metal types in Korea [i.e. Koryŏ] dynasty', 'Bok types and Jun types of Korea Dynasty'.

5 Cheongju Early Printing Museum, 'The process of making metal types'.

6 Burger, 'Minting', p. 383.

Table 33 Provincial printing offices established in the second half of the nineteenth century

\begin{tabular}{|c|c|c|c|c|}
\hline Name & Place & $\begin{array}{l}\text { Year of } \\
\text { establish- } \\
\text { ment }\end{array}$ & Founders & Remarks \\
\hline $\begin{array}{l}\text { Jinling shuju 金陵官書 } \\
\text { 局, renamed Jiangnan } \\
\text { guan shuju 江南官書 } \\
\text { 局in the early years of } \\
\text { Guangxu }\end{array}$ & $\begin{array}{l}\text { First } \\
\text { Anqing, } \\
\text { then } \\
\text { Nanjing }\end{array}$ & 1864 & $\begin{array}{l}\text { Zeng Guofan 曾 } \\
\text { 國藩 }\end{array}$ & \\
\hline $\begin{array}{l}\text { Jiang Chu shuju 江 } \\
\text { 楚書局 }\end{array}$ & Nanjing & 1901 & $\begin{array}{l}\text { Liu Kunyi 劉坤一, } \\
\text { Zhang Zhidong 張 } \\
\text { 之洞 }\end{array}$ & \\
\hline $\begin{array}{l}\text { Suzhou shuju 蘇州書 } \\
\text { 局, alternative name } \\
\text { Jiangsu shuju 江蘇 } \\
\text { 書局 }\end{array}$ & Suzhou & 1865 & $\begin{array}{l}\text { Li Hongzhang 李 } \\
\text { 鴻章 }\end{array}$ & \\
\hline $\begin{array}{l}\text { Huainan shuju 淮南 } \\
\text { 書局 }\end{array}$ & Yangzhou & 1869 & $\begin{array}{l}\text { Salt Commissioner } \\
\text { Fang Junyi 方濬頣 }\end{array}$ & \\
\hline $\begin{array}{l}\text { Zhejiang guan shuju } \\
\text { 浙江官書局 }\end{array}$ & Hangzhou & $\begin{array}{l}1864 \text { (alt. } \\
\text { date 1867) }\end{array}$ & $\begin{array}{l}\text { Provincial } \\
\text { Treasurer Yang } \\
\text { Changjun 楊昌浚, } \\
\text { Provincial Judge } \\
\text { Wang Kaitai 王 } \\
\text { 凱泰 }\end{array}$ & $\begin{array}{l}\text { Greatest output. } \\
\text { Over } 100 \text { and } \\
\text { several dozen titles. In } \\
20 \text { years, } 200 \text { titles. } \\
\text { Printed 浙江通 } \\
\text { 志 (1899). Merged } \\
\text { in } 1909 \text { with the } \\
\text { Zhejiang library. }\end{array}$ \\
\hline $\begin{array}{l}\text { Qushui shuju 曲水書 } \\
\text { 局 (Anhui shuju 安徽 } \\
\text { 書局 or Anhui fuwen } \\
\text { shuju 安徽敷文書局) }\end{array}$ & Changzhou & 1863 & & $\begin{array}{l}\text { The Fuwen shuju used } \\
\text { wooden movable } \\
\text { types. }\end{array}$ \\
\hline
\end{tabular}




\begin{tabular}{|c|c|c|c|c|}
\hline Name & Place & $\begin{array}{l}\text { Year of } \\
\text { establish- } \\
\text { ment }\end{array}$ & Founders & Remarks \\
\hline $\begin{array}{l}\text { Fujian Fuzhou shuju } \\
\text { 福建福州書局 }\end{array}$ & Fuzhou & 1866 & $\begin{array}{l}\text { Gov.-General Zuo } \\
\text { Zongtang }\end{array}$ & \\
\hline $\begin{array}{l}\text { Hubei guan shuju 湖 } \\
\text { 北官書局, alternative } \\
\text { name Chongwen } \\
\text { shuju 崇文書局 }\end{array}$ & Wuchang & 1867 & $\begin{array}{l}\text { Gov.-General of } \\
\text { Huguang and } \\
\text { Gov. of Hubei, Li } \\
\text { Hanzhang 李瀚章 }\end{array}$ & $\begin{array}{l}\text { Hubei shuju and } \\
\text { Chongwen shuju } \\
\text { were originally sepa- } \\
\text { rate and later merged. } \\
\text { Output } 250 \text { titles, } \\
140,000 \text { printing } \\
\text { blocks. Printed Hubei } \\
\text { tongzhi. Received } \\
\text { financial subsidies } \\
\text { by Li Hanzhang and } \\
\text { Zhang Zhidong. In } \\
\text { peak times employed } \\
60 \text { to } 70 \text { letter- } \\
\text { carvers, printers, and } \\
\text { binders. }\end{array}$ \\
\hline $\begin{array}{l}\text { Hunan guan shuju湖 } \\
\text { 北官書局, alternative } \\
\text { names Xiangnan } \\
\text { shuju 湘南書局, Hubei } \\
\text { sixian shuju 湖北思 } \\
\text { 賢書局 }\end{array}$ & Changsha & 1865 & & $\begin{array}{l}\text { Focus on the works of } \\
\text { contemporary writers }\end{array}$ \\
\hline $\begin{array}{l}\text { Jiangxi guan shuju 江 } \\
\text { 西官書局 }\end{array}$ & Nanchang & 1863 & & \\
\hline $\begin{array}{l}\text { (Guangdong) } \\
\text { Guangya shuju（廣 } \\
\text { 東）廣雅書局 }\end{array}$ & Guangzhou & 1886 & $\begin{array}{l}\text { Gov.-Gen. of } \\
\text { Hu-Guang, Zhang } \\
\text { Zhidong 張之洞, } \\
\text { director Wang } \\
\text { Binsi 王秉思 }\end{array}$ & $\begin{array}{l}\text { Funds raised by } \\
\text { Zhang Zhidong. } \\
\text { Output ca. } 300 \\
\text { titles. Had its own } \\
\text { catalogue. }\end{array}$ \\
\hline $\begin{array}{l}\text { Shanxi guan shuju山 } \\
\text { 西官書局, originally } \\
\text { Junwen shuju 浚/濬 } \\
\text { 文書局 }\end{array}$ & Taiyuan & 1879 & $\begin{array}{l}\text { Gov. Zeng } \\
\text { Guoquan 曾国荃 }\end{array}$ & Printed Shanxi tongzhi \\
\hline $\begin{array}{l}\text { Shandong guan } \\
\text { shuju 山東官書局, } \\
\text { alternative name } \\
\text { Shandong huanghua } \\
\text { shuju 山東皇華書局 } \\
\text { (Shandong Imperial } \\
\text { China Printery) }\end{array}$ & Jinan & $1869-1870$ & $\begin{array}{l}\text { Ding Baozhen丁 } \\
\text { 寶楨 }\end{array}$ & $\begin{array}{l}\text { Relatively high- } \\
\text { quality prints. }\end{array}$ \\
\hline
\end{tabular}




\begin{tabular}{|c|c|c|c|c|}
\hline Name & Place & $\begin{array}{l}\text { Year of } \\
\text { establish- } \\
\text { ment }\end{array}$ & Founders & Remarks \\
\hline $\begin{array}{l}\text { Zhili guan shuju 直隸 } \\
\text { 官書局 }\end{array}$ & $\begin{array}{l}\text { First } \\
\text { Baoding } \\
\text { then Tianjin }\end{array}$ & 1881 & $\begin{array}{l}\text { Lao Naixuan勞乃 } \\
\text { 宣, director Sun } \\
\text { Jianai 孫家畾 }\end{array}$ & $\begin{array}{l}\text { Initially planned to } \\
\text { focus on 'modern' } \\
\text { topics. But since } \\
\text { it didn't receive a } \\
\text { budget for printing, } \\
\text { it did not produce its } \\
\text { own imprints. Instead, } \\
\text { since } 1896 \text { they were } \\
\text { transported by the } \\
\text { CMSNC from southern } \\
\text { official printeries and } \\
\text { sold by this office at } \\
\text { the original price. }\end{array}$ \\
\hline $\begin{array}{l}\text { Sichuan cungu } \\
\text { shuju 四川存古書 } \\
\text { 局 (Sichuan Printing } \\
\text { Office for Conserving } \\
\text { Antiquity), Chengdu } \\
\text { shuju 成都書局 }\end{array}$ & Chengdu & 1863 & Wu Tang 吳棠 & \\
\hline $\begin{array}{l}\text { Yunnan shuju 雲南 } \\
\text { 書局 }\end{array}$ & Kunming & 1880 & Songfan 崧藩 & $\begin{array}{l}\text { Zhang Xiumin: } \\
\text { 'relatively small } \\
\text { output' }\end{array}$ \\
\hline $\begin{array}{l}\text { Guizhou shuju 貴州 } \\
\text { 書局 }\end{array}$ & Guiyang & 1896 & Songkun 嵩昆 & $\begin{array}{l}\text { Zhang Xiumin: } \\
\text { 'relatively small } \\
\text { output' }\end{array}$ \\
\hline $\begin{array}{l}\text { Henan guan shuju 河 } \\
\text { 南官書局 }\end{array}$ & & 1884 & & \\
\hline $\begin{array}{l}\text { Lanzhou (Gansu) } \\
\text { guan shuju 蘭州官 } \\
\text { 書局 }\end{array}$ & Lanzhou & 1903 & & \\
\hline $\begin{array}{l}\text { Zunjing shuyuan 尊 } \\
\text { 敬書院 }\end{array}$ & Qinghai & unclear & $\begin{array}{l}\text { Long Xiqing 龍 } \\
\text { 錫慶 }\end{array}$ & $\begin{array}{l}\text { Only in Zhang } \\
\text { Shudong, sect. 14-1 }\end{array}$ \\
\hline Dihua shuju 迪化書局 & Urumchi & 1880 & $\begin{array}{l}\text { Zuo Zongtang左 } \\
\text { 宗棠 }\end{array}$ & $\begin{array}{l}\text { Only in Zhang } \\
\text { Shudong, sect. 14-1 }\end{array}$ \\
\hline $\begin{array}{l}\text { Guiyuan shuju 桂垣 } \\
\text { 書局, in } 1907 \text { Guangxi } \\
\text { shuju 廣西書局 }\end{array}$ & Guilin & 1890 & Ma Piyao 馬丕瑤 & $\begin{array}{l}\text { Only in Zhang } \\
\text { Shudong, sect. 14-1 }\end{array}$ \\
\hline
\end{tabular}

Sources: Zhang Shudong, Zhongguo yinshua, chap. 7, sect. 6-5, (5), 1. (3); chap. 14, sect. 1 各地官书 局 (www.cgan.net/book/books/print/g-history/big5_12/14_1.htm\#1411); Qingdai yinshua; Zhang Xiumin, Zhongguo yinshua shi, p. $559 \mathrm{ff}$. 
